\title{
Pemanfaatan Facebook selama Masa Pandemi Covid-19 Di Masjid Nurul Huda, Ngoto, Sewon, Bantul, Yogyakarta

\author{
Rahma Attaymini
}

\author{
Fakultas Ilmu Sosial dan Humaniora, \\ Universitas Islam Negeri Sunan Kalijaga Yogyakarta \\ Email Penulis: rahmah.attaymini@uin-suka.ac.id
}

\begin{abstract}
ABSTRAK
Kemajuan teknologi dan informasi kini membuat segala aktivitas terasa menjadi lebih efisien, terlebih persoalan pemanfaatan media sosial. Perkembangan teknologi komunikasi ini mendorong pelaku komunikasi yang tidak hanya digunakan oleh individu saja, tapi menjadi sebuah alternatif yang digunakan oleh pengelola rumah ibadah dalam hal ini (masjid) untuk dapat memberikan informasi dan edukasi dakwah dan kegiatan-kegiatan keagamaan di masjid melalui platform media sosial yaitu Facebook. Permasalahan pada penelitian ini adalah bagaimana media sosial Facebook dapat digunakan sebagai media komunikasi keagamaan yang bersifat edukatif dan informatif saat pemberlakukan social distancing di masa pandemi Covid-19 melalui metode deskriptif-kualitatif. Pengumpulan data pada penelitian ini adalah wawancara mendalam dengan informan yang berasal dari pengelola media sosial dan masyarakat, foto atau video dokumentasi. Hasil penelitian menunjukan bahwa komunikasi digital di media sosial Facebook Masjid Nurul Huda Ngoto dapat digunakan sebagai media komunikasi keagamaan yang efektif, media penyebaran dakwah yang edukatif dan informatif karena selain masyarakat mendapatkan informasi baru seputar kegiatan keagamaan di masjid, masyarakat tetap merasakan semangat dan semaraknya beribadah di rumah masing-masing pada masa pandemi Covid-19
\end{abstract}

Kata-kata kunci: Media Sosial, Facebook, Social Distancing, Masjid

\section{The utilization of facebook at Nurul Huda Mosque, Ngoto, Sewon Bantul during Pandemic Covid-19}

\begin{abstract}
Advances in technology and information now make all activities feel more efficient, especially the issue of using social media. The development of this communication technology encourages communication actors who are not only used by individuals but become an alternative used by managers of houses of worship in this case (mosques) to be able to provide information and education on da'wah and religious activities in mosques through social media platforms, namely Facebook. The problem in this study is that researchers will analyze how Facebook social media can be used as a medium for religious communication that is educational and informative when implemented social distancing is during the Covid-19 pandemic through a qualitative-descriptive method. Data collection in this study was in-depth interviews with informants from social media and community managers, photos or video documentation. The results showed that digital communication on the social media Facebook Nurul Huda Ngoto Mosque can be used as an effective religious communication media, educational and informative propagation media because in addition to the public getting new information about religious activities in mosques, people still feel the enthusiasm and liveliness of worshiping at the mosque in their respective homes during the Covid-19 pandemic
\end{abstract}

Keywords: Facebook, Mosque, Social Media, Social Distancing,

Published: September 2020

ISSN: 2622-5476 (cetak), ISSN: 2655-6405 (online) Website: https://jurnal.amikom.ac.id/index.php/pikma 


\section{PENDAHULUAN}

Proses komunikasi kini telah diberikan kemudahan yang sangat besar berkat hadirnya teknologi. Kemudahan layanan itu dengan adanya jaringan internet. Komunikasi yang terjadi di dunia maya kini terasa sangat mudah.

Banyak Penyebutan yang bisa disematkan untuk media siber (cyber media) dalam literatur akademis, misalnya media online, digital media, media virtual, e-media, network media, media baru, dan media web. (Nasrullah: 2014). Komunikasi ini disebut dengan komunikasi di ruang siber (cybermedia), komunikasi yang dilakukan dengan teknologi yang ada ini biasa disebut sebagai komunikasi digital.

Komunikasi berteknologi digital kini mengalami perkembangan yang signifikan dan melahirkan beragam jenis media komunikasi dari media yang paling rumit sampaipada yang paling mudah digunakan untuk aktivitas kehidupan kita sehari-hari, seperti telepon genggam yang sangat fleksibel dan mudah dibawa kemanapun. Kemudian fungsi dari media komunikasi yang digunakan tidak hanya untuk menanyakan kabar kepada teman atau saudara bahkan kini sangat populer untuk ladang bisnis masyarakat zaman sekarang.
Asosiasi Penyelenggara Jasa Internet Indonesia (APJII) memaparkan dari data yang diperoleh ada 171,17 juta masyarakat Indoensia yang aktif sebagai pengguna internet pada tahun 2018 lalu, sejak data ini rilis jumlah masyarakat Indonesia pengguna internet di Tanah Air semakin bertambah tiap tahunnya dari total populasi penduduk Indonesia yang menapai jumlah 264,14 juta orang yang terkoneksi dengan jaringan interne, ada penambahan sekitar 27,9 juta pengguna internet dari tahun sebelumnya. (Tri, 2019).

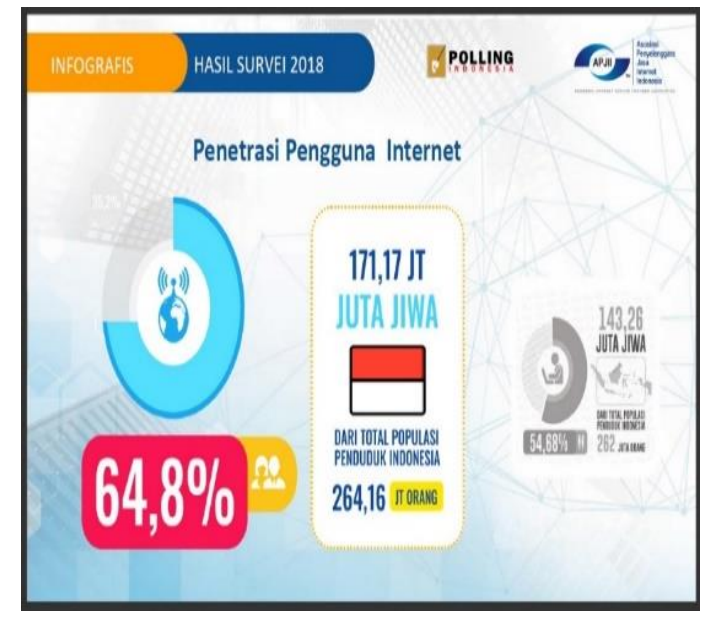

Gambar 1: Hasil survei APJII tahun 2018 tentang data penetrasi pengguna Internet di Indonesia

Berkat perkembangan teknologi saat ini mengirimkan pesan dapat dilakukan dimana saja dengan sangat mudah melalui ruang-ruang di media siber, salah satu jenis media siber yang banyak digunakan adalah media sosial. Media sosial sekarang beraneka ragam bentuknya 
dari mulai Facebook, Twitter, Instagram, aplikasi chat WA, Line, Youtube dan lain sebagainya.

$$
\text { Ada banyak cara untuk }
$$
berkomunikasi di media sosial, salah satu media sosial yang banyak digunakan oleh masyarakat Indonesia adalah Facebook. Sejak kemunculan Facebook masyarakat dapat sangat mudah berbagi informasi dan aktivitas sehari hari melalui status, unggahan foto atau video, ini yang menjadikan Facebook menjadi media sosial yang favorit di seluruh dunia termasuk bagi masyarakat Indonesia. Dari data yang ditemukan We Are Social Negara Indonesia menjadi Negara pengguna media sosial Facebook terbanyak se Asia Tenggara berada di nomor urut 1 dan urutan nomor 4 di tingkat dunia. Sampai bulan Januari 2018 lalu Indonesia mencapai sekitar 130 juta akun pengguna Facebook dengan persentase $6 \%$ dari total keseluruhan penggunanya. (Chandra, 2018)

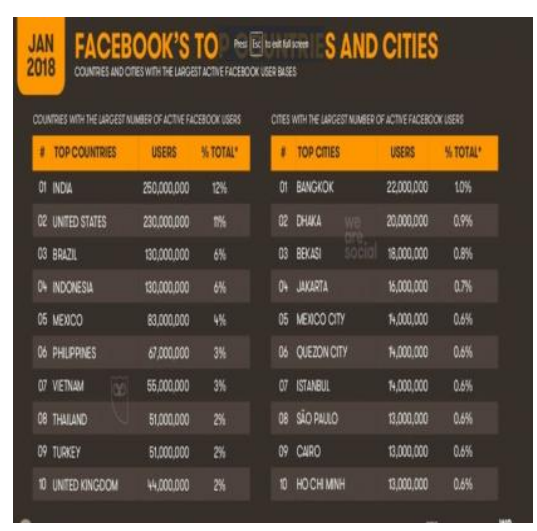

Gambar 2: Data dari Urutan Negara-Negara dengan jumlah pengguna Facebook terbanyak (We Are social, 2018)

Media sosial Facebook memiliki beragam keunggulan yang tidak dapat dimiliki oleh situs media sosial lainnya, Facebook kini dibekali beragam fitur-fitur canggih dan menarik serta aman digunakan. Keunggulan-keungguan yang dimiliki Facebook diantaranya yaitu fitur berbagi informasi kepada orang lain, berbagi foto, video, status dll saja tapi kini Facebook mampu hadir sebagai seorang promotor (orang yang mempromosikan suatu barang) yang kompoten dan handal dalam bertugas menjadi komunikator pemasaran suatu produk barang dan jasa (Madcoms, 2010:1)

Sejak tanggal 11 Maret 2020 WHO mengumumkan bahwa Coronavirus Disease -19 (Covid-19) menjadi pandemi global (Putri, 2020). Tidak butuh banyak waktu pasca diumumkan WHO menjadi pandemi global kasus positif Covid-19 di Indonesia terus melonjak tajam, hingga hari ini 24 Agustus 2020 tercatat sudah ada sekitar 155.412 orang dinyatakan positif, 111.060 orang pasien dinyatakan sembuh dan 6.759 orang meninggal (https://covid19.go.id).

Pada tanggal 3 Maret 2020 lalu Presiden Joko Widodo menandatangani Peraturan Presiden Nomor 21 Tahun 2020 mengenai adanya penerapan sistem (PSBB) Pembatasan Sosial Berskala Besar 
yang bertujuan untuk menghambat penyebaran virus yang sedang berkembang di Indonesia, kondisi ini tentu berdampak pada kekhawatiran dan psikologis masyarakat Indonesia. Daerah-daerah dengan status zona merah atau daerah yang rawan penyebaran virus telah lebih dulu melakukan lockdown lokal secara swadaya oleh masyarakat dan pemerintah daerah sekitar. Tentu saja ini berdampak pada aktivitas di tempat ibadah (masjid) dan aktivitas sehari-hari masyarakat yang serba dilakukan secara terbatas, masyarakat harus berdiam diri di rumah, bekerja dari rumah, anak-anak harus belajar di rumah dan menerapkan social distancing dan protokol kesehatan secara ketat.

Di tengah peringatan yang dikeluarkan pemerintah untuk menjaga kesehatan diri dan penerapan social distancing yang digalakkan oleh pemerintah Indonesia. Masjid sebagai tempat ibadah yang banyak digunakan untuk aktivitas dengan jumlah besarpun juga harus menjaga diri dari tuduhan sebagai faktor penyebaran virus, oleh karenanya masjid harus bekerja keras berperan aktif dalam menyebarkan informasi bermutu dan bermanfaat bagi masyarakat tentang anjuran pemerintah menjaga kesehatan dan mengurangi aktivitas di luar rumah yang tidak perlu, hal ini mau tidak mau membuat para pengurus dan takmir Masjid Nurul Huda Ngoto harus memutar otak memikirkan hal itu.

Banyak kegiatan dakwah dan keagamaan di Masjid Nurul Huda Ngoto yang tidak dapat terlaksana, mulai dari sholat berjamaah di masjid yang jelas sudah tidak diperbolehkan untuk sementara waktu, kegiatan-kegiatan yang sifatnya mengumpulkan jamaah dalam jumlah besar harus terpaksa ditunda, salah satunya pengajian akhirussanah, buka puasa Bersama dan ziarah wali yang biasa tiap tahun dilakukan tahun ini terpaksa harus ditunda sampai waktu yang tidak dapat ditentukan.

Namun hal ini tidak lantas menyurutkan semangat masyarakat sekitar, pengurus dan para takmir mencari cara agar kegiatan keagamaan tetap berjalan. Pada bulan Ramadhan Sholat tarawih yang biasa dilakukan secara berjamaah di masjid tetap berjalan yakni dengan tetap mengadakan sholat tarawih berjamaah hanya 3 orang saja di masjid kemudian sholat tarawih berjamaah yang hanya 3 orang tadi disiarkan secara langsung melalui pengeras suara yang sudah dipasang di setiap lorong/gang rumah masyarakat, kegiatan ini juga disiarkan secara langsung melalui akun Facebook masjid, hal ini sempat menjadi trending dan viral di jagat media sosial. 
Berdasarkan dari fenomena diatas, peneliti tertarik untuk menganalisis bagaimana penggunaan media sosial Facebook dapat digunakan sebagai media komunikasi keagamaan dan penyebaran dakwah yang edukatif dan informatif saat pemberlakukan social distancing di masa pandemi Covid-19. Dimana dalam penelitian ini berfokus pada bagaimana pemanfaatan komunikasi digital di media sosial Facebook Masjid Nurul Huda Ngoto dalam menginformasikan dan mengedukasi masyarakat untuk tetap semangat dan menumbuhkan kesadaran bahwa Ibadah dapat dilakukan dimanapun saja dan dalam kondisi apapun.

\section{METODOLOGI}

Penelitian ini menggunakan metode deskriptif-kualitatif. Penelitian kualitatif lebih menekankan pada kedalaman dari sumber informasi yang didapat. (Moleong: 2006). Penelitian ini bertujuan untuk memberikan gambaran bagaimana pemanfaatan komunikasi digital yang terjadi di media sosial Facebook Masjid Nurul Huda Ngoto terlaksana dengan baik sebagai bentuk alternatif pemberlakukan social distancing saat pandemi Covid-19 terkhusus pada kegiatan-kegiatan dakwah dan keagamaan di masjid yang dilakukan mengikuti standar protokol kesehatan dan kenormalan baru yang berlaku di Indonesia.

Adapun teknik pengumpulan data yang dipakai pada penelitian ada tiga yakni sebagai berikut: Pertama observasi langsung atau biasa disebut dengan pengamatan langsung yaitu di Masjid Nurul Huda Ngoto yang mana tempat tersebut merupakan pusat kegiatan keagamaan masyarakat Padukuhan Ngoto, Desa Bangunharjo. Pengumpulan data selanjutnya yakni berupa wawancara mendalam (in-dept interview) dengan masyarakat dan pengelola media sosial masjid yang bertujuan membangun kedekatan sehingga berbagai informasi seputar kegiatan keagamaan selama masa pandemi Covid-19 di dapatkan oleh peneliti dengan cara mengajukan pertanyaan dan akan dijawab secara lisan dengan jawaban yang sebenar-benarnya. Dan yang terakhir adalah dokumentasi yang mana peneliti selalu mengabadikan saat proses penelitian berlangsung maupun perekaman video atau foto yang sudah ada.

\section{HASIL DAN PEMBAHASAN}

Penelitian deskriptif kualitatif adalah penelitian dengan menggunakan bahasa-bahasa yang santun dan sistematis sebagai bentuk gambaran dari data yang sudah diperolah dan diolah oleh peneliti 
dilapangan (lokasi penelitian) yang berasal dari informan atau narasumber, foto dan video dokumentasi yang ada. Penelitian ini dimulai dengan proses komunikasi yang efektif dimana kunci keberhasilan dari komunikasi yang efektif itu terletak pada kesesuaian respon yang diberikan narasumber yang diharapkan oleh peneliti.

\section{Interaksi dalam Penggunaan Media}

\section{Sosial Facebook}

Berbicara mengenai media sosial sebagaimana yang kita ketahui bersama bahwa media sosial adalah bagian dari media daring, media soial dapat membantu dan menghubungkan segala aktivitas penggunanya, para penggunanya atau biasa disebut user dapat dengan mudah berbagi informasi, dan menciptakan konten media sosialnya kepada orang lain di belahan dunia manapun. Media sosial yang paling lazim digunakan oleh masyarakat di seluruh dunia diantaranya yaitu media sosial yang berbentuk jejering sosial seperti WhatsApp, Instagram, Facebook, Twitter dan sebagainya

$$
\text { Media sosial memiliki }
$$

karakteristik-karakteristik spesifik tertentu. Adapun karakteristik-karakteristik interaksi yang dimiliki media sosial antara lain adalah menurut Mayfield (2008) Karakteristik pertama Participation maksudnya adalah bahwa media sosial memiliki peran untuk menghadirkan proses timbal balik dan partisipasi audience satu sama lain dari siapapun yang tergabung di media itu. Kedua, karakteristik Openess maksudnya adalah bahwa adanya sifat terbuka yang diberikan oleh media sosial pada proses timbal balik dan partisipasi satu sama lain sehingga timbul adanya komentar, adanya pemilihan dan perputaran informasi itu sendiri.

Ketiga, Conversation yang bermaksud jika dulu perputaran informasi dilaksanakan dan diidistribusikan melalui satu arah (komunikasi satu arah) tapi kini media sosial menjadi komunikasi yang bersifat dua arah karena ada timbal balik di dalamnya. Karakteristik keempat yaitu Community dimana artinya media sosial berfungsi sebagai sebuah komunitas yang melingkupi beragam masyarakat dengan hobi dan ketertarikan tertentu terhadapat sesuatu. Karakteristik terakhir adalah Connectedness artinya disini media sosial memiliki konektivitas atau berfungsi sebagai penghubung antar obyek satu dengan obyek lainnya, sebagai contoh memberikan link kepada audience pada suatu situs dan informasi tertentu.

"Kalau menurut saya media sosial itu seperti penghubung antara si A dan si B menghubungkan komunikasi yang mau disampaikan ada koneksi gitulah mbak...hehe trus kita kayak orang ngobrol kayak di kolom komentar saling berbalas omongan langsung di 
kolom itu. (JMRT, Masyarakat, 40 Tahun)"

Dari pemaparan narasumber diatas, menjelaskan bahwa karakteristik interaksi yang ada di media sosial itu dapat sangat mudah dirasakan dan disadari oleh mayarakat. Kehadiran media sosial menjadi penghubung dan medium atau tempat terjadinya interaksi komunikasi digital, apa pesan yang disampaikan kepada publik kemudian direspon oleh publik lain. Jejaring sosial (social network) tidak hanya dimanfaatkan sebagai medium untuk menemukan kawan lama saja tapi lebih dari itu, di media sosial kita dapat saling bertegur sapa satu sama lainnya walaupun berada di kota yang terpisah, dapat bertukar foto, dan video dan sebagainya.

Dari jawaban narasumber dapat dianalisis bahwa media sosial masjid bisa difungsikan sebagai tempat atau wadah untuk berbicara dan berdiskusi atau sekedar berbagi informasi kepada masyarakat di ranah digital atau dapat disebut komunikasi digital seperti karakteristik conversation.

Karakter di atas yang menyebutkan bahwa media komunikasi kini bersifat dua arah yang artinya terjadinya percakapan dan timbal balik di suatu grup atau komunitas di antara para user, hal itulah yang dirasakan masyarakat dengan adanya kehadiran media sosial milik masjid.
Masyarakat dapat terhubung dengan informasi terbaru saling berbicara (ngobrol) di dunia maya dan tetap mengetahui aktivitas dan kegiatan yang dilakukan masjid walapun masjid untuk sementara waktu masih ditutup karena Covid-19.

Kemampuan media sosial salah satunya adalah dapat menyebar luaskan informasi atau berita tentang apapun dengan mudah dan cepat di sebuah jaringan yang tersedia. Informasi ketika telah tersebar kepada masyarakat, maka informasi tersebut tidak dapat ditarik kembali artinya berita atau informasi tersebut telah sampai kepada masyarakat dan sudah menjadi konsumsi publik. Oleh karenanya perlu kesadaran dari kita semua dalam menggunakan dan menyebarluaskan suatu informasi atau berita kepada masyarakat agar tidak terjadi penyebaran hoaks atau berita bohong yang berasal dari sumber yang kurang valid.

Sebagaimana yang kita ketahui bersama dalam setiap lini kehidupan kita media sosial hadir memberikan kemudahan bagi kita tentunya dengan keberadaan media sosial ini memeiliki dampak yang sangat besar bagi masyarakat, baik dampak yang baik dan dampak buruk. Dampak baiknya antara lain dapat mendukung segala kehidupan dan aktivitas masyarakat yang dibutuhkan, sementara dampak buruknya walaupun 
tidak merusak, tetapi cukup mengganggu atau menghambat kehidupan individu maupun kelompok masyarakat.

Sebagai contoh media sosial seorang anak, remaja bahkan orang tua harus menyelesaikan pekerjaan dari sekolah ataupun dari kantor tapi dengan kehadiran media sosial pekerjaan yang awalnya sulit dapat selesai dengan mudah, disisi lain media sosial juga sedikit memberikan dampak buruk kepada merek, tersedianya informasi yang seharusnya belum boleh mereka peroleh dan dikonsumsi, tentunya dapat membahayakan kehidupan mereka, dampak lainnya adanya tsunami informasi yang berarti kebanjiran informasi (overload) di media jejaring sosial sehingga harus melakukan sortir yang cukup terhadap konten media sosial tersebut. (Hampton, 2011: California Adolecent Health, 2011).

Media sosial memiliki kemampuan menyebarkan informasi tentang apapun dengan cepat pada jaringan yang sangat luas, dan ketika informasi itu tersebar, pemilik informasi pertama yang menaruhnya dalam jaringan (posting) tidak dapat menariknya kembali atau menghapusnya dari anggota jaringan yang menerimanya.

"Banyak sekali manfaat bagi saya dan masyarakat tidak pernah terbayang kalau masjid ditutup mbonten oleh berkegiatan dakwah sama sekali, padahal banyak kegiatan yang akan dilakukan ziaroh wali, pengajian akhirussanah dll, akeh mbak kegiatan masjid niki...tapi untung Pak Yayi punya ide untuk pasang pengeras suara di setiap gang biar do denger kabeh, trus live di FB nanti biar anak mudanya gak males-males dan tetap semangat mereka kan pasti nyekel HP pasti liat postingane masjid, ini juga bentuk alternatif penyebaran gerakan dakwah kepada masyarakat to mbak di tengah pandemi...(Ed, Pengelola Medsos, 39 Tahun)"

Dengan adanya media sosial Facebook menjadi tempat atau wadah untuk membagikan informasi dan kegiatan dakwah dan keagamaan masjid, ini merupakan salah satu dampak yang baik dari penggunaan media sosial. Facebook menjadi medium penyebaran informasi yang sangat cepat oleh karena itu tidak heran kenapa di masjid media sosial ini juga digunakan untuk aktivitas kegiatan sehari masjid. Melalui media sosial Facebook informasi dapat tersebar secara cepat dan menyeluruh kepada seluruh masyarakat.

Media sosial Facebook menjadi media sosial yang terfavorit dan semakin terkenal di semua kalangan serta karena dapat diakses diamanapun dan kapanpun oleh siapa saja, memiliki jaringan yang memadai dan cukup stabil. Inilah yang akhirnya memutuskan pengelola Masjid 
Nurul Huda Ngoto memilih Facebook sebagai media penyebaran dakwah islam kepada masyarakat dan sekaligus sebagai media untuk menyebarkan dan memberikan informasi seputar kegiatan keagamann di Masjid Nurul Huda Ngoto memilih media jejaring sosial Facebook dikarenakan Facebook semakin terkenal dan dapat diakses oleh siapa saja di hampir seluruh pelosok Indonesia selama tersedia jaringan internetnya yang memadai dan mencukupi.

Para pengguna internet rata-rata menghabiskan waktunya lebih banyak untuk bermain di Facebook (dengan ratarata 7 jam per bulan), dibandingkan dengan mereka yang lainnya yang menghabiskan waktunya di google, Yahoo, YouTube, Microsoft, Wikipedia, dan Amazon.

\section{Media Sosial dan Covid-19 di Masjid}

Pandemi Covid-19 yang tengah melanda kita saat ini merupakan salah satu bencana kemanusiaan bagi masyarakat Indonesia dan bahkan di seluruh dunia secara global. Banyak korban nyawa manusia setiap harinya bertambah dari hari ke hari, tidak hanya masyarakat biasa saja yang meninggal dunia, tetapi dari semua lapisan masyarakat terkena dampak dari pandemi Covid-19 ini, banyak pula tenaga kesehatan kita yang telah berjuang membantu para pasien di rumah sakit pun ikut menjadi korban, pemerintah dan bahkan beberapa kepala negara lain pun juga ikut terdampak, hal ini tentunya menjadi keprihatinan besar bagi kita bersama.

Adanya pandemi Covid-19 ini tentunya membuat kepanikan bagi masyarakat Indonesia, masyarakat kini menjadi lebih religius dan mendekatkan diri kepada Tuhan YME, kalau biasa masyarakat khususnya muslim setiap sholat 5 waktu selalu berjamaan dimasjid namun sekarang harus terbiasa untuk berjamaah di rumah dengan keluarganya saja, terlebih lagi saat memasuki Bulan Ramadhan 1441 Hijriyah.

Bagi umat muslim ibadah puasa dan sholat tarawih berjamaah merupakan momentum yang sangat dinantikan, mereka biasa bercengkrama dan berkumpul setelah sholat tarawih berjamaah harus sejenak melupakan kebiasaan itu dan menggantinya dengan kebiasaan baru yang dengan di rumah saja. Kebiasaan-kebiasaan atau tradisi saat menyambut bulan puasa juga terpaksa ditiadakan dalam kurun waktu yang belum pasti. Ditambah lagi dari sektor pendidikan juga ikut terdampak anak-anak sekolah dari PAUD, TK, SD sampai Perguruan Tinggi terpaksa harus untuk berdiam diri dan belajar dari rumah masing-masing.

Pembatasan mobilitas dan aktivitas inilah membuat penduduk hanya bisa 
beraktivitas dari rumah saja. Di saat inilah internet menjadi sarana pengisi waktu yang paling manjur untuk "membunuh waktu". Hal tersebut membuat penggunaan internet semakin meningkat yang disertai akses internet yang semakin cepat dan semakin luas. Lonjakan pengguna internet tentu menjadi hal yang tak dapat dihindarkan. Meningkatnya jumlah pengguna internet secara signifikan tentu dapat dimanfaatkan pemerintah dan masyarakat untuk menyebarkan informasi terkait langkah preventif pencegahan penularan Covid-19.

Salah satunya dengan memanfaatkan platform media sosial. Masyarakat banyak menghhabiskan waktu untuk berselancar di dunia maya, hal ini dimanfaatkan pengolal masjid untuk tetap aktif dan secara edukatif hadir memberikan kesegaran informasi kepad masyarakat terkait aktivitas dan kegiatan keagamaan yang dilaksanakan di masjid.

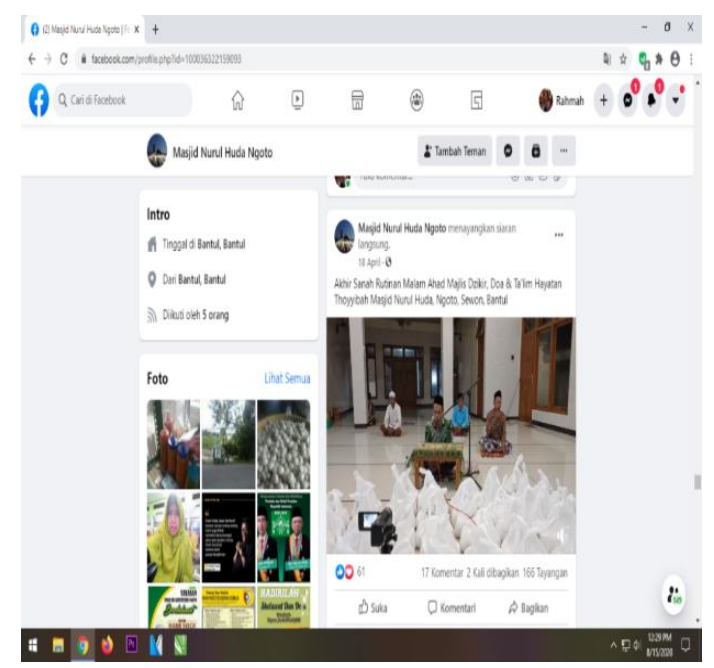

Gambar 3: Suasana pengajian akhirussanah yang diikuti 4 org pengurus masjid

Di media sosial Facebook Masjid Nurul Huda Ngoto tergambarkan bagaimana pengelola media sosial ini mampu mengambil alternative gerakan dakwah penyebaran dakwah islam dan kegiatan-kegiatan keagamaan masjid melalui komunikasi di media sosial Facebook.

$$
\text { Pengelola media sosial }
$$
memberikan edukasi dan informasi pada setiap kegiatan keagamaan di masjid kegiatan dakwah kepada masyarakatpun tersampaikan saat pandemi Covid-19 ini yang membuat kehidupan di masjid tetap hidup dan berjalan lancar dengan menerapkan protokol kesehatan di setiap kegiatan.

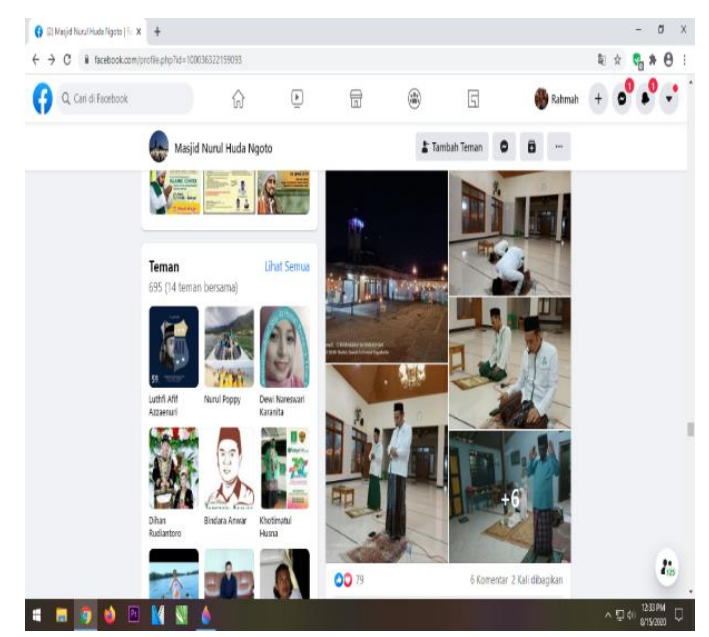

Gambar 4: Suasana saat sholat tarawih berjamaah yang disiarkan langsung secara live di laman Facebook

Dari pengamatan dan observasi yang telah dilakukan di media sosial Facebook milik Masjid Nurul Huda 
Ngoto, melalui siaran langsung ini menggambarkan aktivitas keagamaan yang biasanya dilakukan secara offline kini juga disiarkan melalui online. Kehadiran sholat tarawih berjamaah yang dilakukan takmir yang hanya berjumlah 3 orang saja kemudian disiarkan live dari Facebook bertujuan untuk menumbuhkan semangat masyarakat agar tetap melaksanakan ibadah berjamaah di rumah masing-masing walaupun kondisi saat ini yang masih sangat kurang memungkinkan untuk beribadah di masjid.

Keunggulan dari Facebook sebagai sebuah media sosial yang sangat populer di Indonesia, media ini juga memiliki kelebihan dalam pemuatan berbagai foto dan kemampuannya dalam menandai (tag) orang-orang yang ada di foto tersebut ini tentunya menjadi fitur yang sangat memikat karena seseorang bisa merasakan terlibat di kegiatan atau acara pada foto itu karena fitur menandai orang tersebut.

Kemudahan lainnya yang dapat dirasakan pengelola masjid ngoto dengan masyarakat sekitarnya adalah dapat menuliskan komentar terhadap status, foto, news feed di Facebook sehingga pengelola dapat merespon dengan cepat tanggapan ataupun komentar masyarakat terhadap foto atau video yang telah diposting.

Kegiatan lain seperti tadarusan juga dilaksanakan live di akun Facebook masjid, acara buka puasa bersama yang biasanya harus mengumpulkan jamaah dalam jumlah banyak tetap dilaksanakan dengan hanya beberapa orang saja yang bertugas mengantarkan dan membagikan makanan untuk berbuka kepada seluruh masyarakat di Padukuhan Ngoto baik muslim dan nonmuslim tanpa terkecuali, kegiatan ini juga disiarkan secara live di media sosial Facebook dan unggahan status.

\section{KESIMPULAN}

Penelitian dengan memanfaatkan penggunaan media melalui komunikasi digital di media sosial Facebook oleh Masjid Nurul Huda Ngoto sudah dimanfaatkan secara baik dan efektif, hal ini sebagai bentuk dari proses komunikasi yang edukatif dan informatif melalui gerakan dakwah Islam dan kegiatankegiatan keagamaan masjid selama masa pandemi Covid-19. Kegiatan dakwah dan kegiatan keagamaan lainnya yang bisa dilakukan secara offline kini dilakukan secara online. Komunikasi ini telah dapat digunakan dengan baik dan dirasakan manfaatnya pula bagi pengelola media sosial masjid dan masyarakat.

Proses komunikasi digital di media sosial masjid dilaksanakan secara berkesinambungan dimulai pada tahap pemberitahun kepada warga atau masyarakat di media sosial Facebook bahwa selama masa lockdown kegiatan 
keagamaan di masjid tetap berjalan walaupun dengan jumlah orang yang terbatas, dari sini menunjukan bahwa komunikasi yang disampaikan bersifat informatif karena pesan tersebut tersampaikan dan dapat dipahami oleh masyarakat.

\section{Media sosial Facebook} memberikan manfaat edukatif dan informatif selama pandemi Covid-19. Semua kegiatan keagamaan masjid mulai dari pengajian akhirussannah, sholat 5 waktu berjamaah, buka puasa bersama dan sholat tarawih berjamaah ditiadakan di masjid, tapi kegiatan ini tetap dilaksanakan dengan menerapkan standar protokol dan jumlah orang yang terbatas yakni hanya pengurus atau para takmir masjid yang tidak lebih dari 5 orang.

Kegiatan-kegiatan dakwah keagamaan ini juga disiarkan secara langsung melalui Facebook masjid dan melalui pengeras suara yang telah dipasang di setiap lorong gang pemukiman warga yang berada tidak jauh dari masjid. Adanya pengeras suara dan live Facebook sifatnya hanya sebagai penggerak dan pemberi informasi bahwa ibadah sholat tarawih telah dimulai. Masyarakat tetap dapat melaksankan ibadah sholat berjamaah dengan keluarganya masingmasing di rumah mereka walaupun ditengah masa pandemi Covid-19.

\section{DAFTAR PUSTAKA}

Divisi Litbang MADCOMS. 2010. Seri Panduan Pemrograman Microsoft Visual Basic 6.0 - Ed II, Yogyakarta: ANDI, Madiun: MADCOMS.

Hampton, Keith N. 2011. Social networking sites and our lives How people's trust, personal relationships, and civic and political involvement are connected to their use of social networking sites and other technologies, Pew Research Center's Internet \& American Life Project. Diakses pada 25 Agustus 2019, dari http:// pewinternet.org/Reports/2011/ Technology-andsocial-networks. Aspx/

Mayfield, Anthony. 2008. What is Social Media?. United Kingdom: Icrossing

Moleong. 2006. Metodologi Penelitian Kualitatif. Edisi Revisi. Bandung: PT. Remaja Rosdakarya.

Nasrullah, Rulli. 2014. Teori dan Riset Media Siber (Cybermedia). Jakarta: Kencana.

Chandra Septania, Rizki. 2018. Indonesia, Pengguna Facebook Terbanyak ke-4 di Dunia. Kompas.com. 02 Maret. Diakses $25 \quad$ Agustus 2020 https://tekno.kompas.com/read/2018/0 3/02/08181617/indonesia-penggunafacebook-terbanyak-ke-4-di-dunia/

Https://covid19.go.id diakses 25 Agustus 2020

Putri, Gloria Setyvani. 2020. WHO Resmi Sebut Virus Corona Covid-19 sebagai Pandemi Global.Kompas.com.12 Maret. Diakses pada 25 Agustus 2020, darihttps://www.kompas.com 
Jurnal PIKMA: Publikasi Media Dan Cinema, Volume 3, No. 1, September 2020, hlm 34-46

/sains/read/2020/03/12/083129823/wh o-resmi-sebut-virus-corona-covid-19sebagai-pandemi-global?page=all/

Tri Haryanto, Agus 2019. Pengguna Internet di Indonesia didominasi Milenial. Detikinet. 19 Mei. Diakses pada 25 Agustus 2020, dari https://inet.detik.com/telecommunicati on/d4551389/pengguna-internetindonesia-didominasi-milenial/ 